\title{
Environmental Management Action (EMA) To Fight Dengue Hemorrhagic Fever In Coastal Areas
}

\author{
Nur Siyam ${ }^{1}$, Widya Hary Cahyati ${ }^{2}$ \\ \{nursiyam@mail.unnes.ac.id ${ }^{1}$, widyahary27@mail.unnes.ac.id ${ }^{2}$ \}
}

Universitas Negeri Semarang, F5 Bild, 2nd Floor Sekaran, Gunungpati, Semarang ${ }^{1,2}$

\begin{abstract}
Genuk Subdistrict is a coastal area which becomes an endemic area for DHF Dengue Hemorrhagic Fever). To build clean and healthy life behavior of school children in preventing and controlling the proliferation of dengue vector mosquitoes, is by applying the Environmental Management Action (EMA). The study was conducted with a one group pretest posttest design. Samples were taken by purposive sampling which are 24 students. The research data was processed using a quantitative descriptive approach. Implementing EMA; 1) Modified Action in the home and surrounding environment, 2) Environmental and surrounding Manipulation Action and 3) Action Changing Behavior of students and Family Members. Data collection instruments are questionnaires. EMA Education Results in schools showed an increase in both Student Knowledge about DHF, Student Attitudes in Preventing DHF, Environmental Modification and Manipulation, and also in Changing Behavior in preventing DHF. The highest increase can be seen in the highest delta, namely the Student Attitude variable in Preventing DHF. EMA education can be an alternative in raising awareness and attitudes of students to maintain their behavior in preventing DHF in their environment.
\end{abstract}

Keywords: Environmental Management Action, environmental manipulation, behavior change, DHF, students.

\section{Introduction}

Early 2019, several regions in Indonesia experienced an outbreak of Dengue Hemorrhagic Fever (KLB DBD). For example, in the Bekasi, DKI Jakarta, Central Java areas such as Sragen, East Java, Gorontalo and other areas experienced an increase in dengue cases in early 2019. Likewise, the incidence of dengue fever in Semarang City has also increased. Early 2019, there were 67 cases of dengue fever in Semarang City.

DHF is a disease that can cause illness and death for sufferers. DHF is a disease caused by the dengue virus which is transmitted through the bite of the Aedes aegypti mosquito as the main vector. Until now, DHF is still one of the public health problems in Indonesia that cannot be controlled optimally. The incidence of DHF can increase due to environmental factors, climate, geographical conditions, behavior, and immunity conditions [1], [2].

One of the efforts that have been made to tackle dengue fever is focused on eradicating adult mosquitoes as transmitters, namely Aedes aegypti [3]. The community needs to get sufficient education and knowledge to be able to carry out vector eradication independently. The eradication of mosquitoes by means of fogging can only kill adult mosquitoes but cannot simultaneously kill mosquito eggs and larvae [4]. 
One of the provinces in Indonesia that is still a dengue endemic area in Central Java is Semarang Regency. The incidence rate (IR) of DHF in Semarang Regency in 2016 has increased compared to the previous year. IR DBD in 2016 was 98.7 per 100,000 population out of 993 cases found and handled. The community still thinks that fogging is the most effective way to eradicate dengue, so it rules out the Eradication of Mosquito Nests (PSN) which is actually the most effective way to eradicate DHF [5].

Genuk Subdistrict is a tidal area which is an endemic area for DHF. Every year the incidence of DHF has increased, even Genuk Subdistrict is ranked number three with the highest number of sufferers. Eradicating mosquito nests in Rob's area really requires the participation and awareness of the community in managing the environment to prevent vector breeding places. The participation of young groups such as school children is needed to help prevent mosquito breeding in their home environment.

SMP Islam Sultan Agung 4 Semarang is located in a coastal area where tidal water will inundate the school environment every 12.00 to 15.00 WIB. Based on the results of interviews with researchers with the school, which in this case is represented by one of the homeroom teachers named Mr. Ahmad Solihul Hadi, M.Pd.I, Al Hafidz, explained that students have health problems related to infectious diseases such as dermatitis, dengue fever, scabies, diarrhea, which are diseases that have become a habit in the school environment and around the school. In addition, the habit of students throwing garbage in any place causes garbage / food wrappers to scatter in the school yard, in parks, and even into drains / sewers. Garbage and food scraps are often found in their desk drawers. This habit will certainly not be much different from their habits in the home environment.

To overcome these problems, students need support and assistance from various parties, including support from friends and school authorities. However, one thing that should not be forgotten is the awareness and concern of the individual students themselves to change and become individuals who are willing to create healthy environmental management actions. In an effort to build a clean and healthy lifestyle in preventing and controlling the reproduction of the dengue mosquito vector, one of them is by implementing the Environmental Management Action Education method [6]. The essence of the application of EMA Education is vector control education by school children in their home environment in the activity of creating a healthy environment free of Aedes aegypti mosquito vectors so that they are willing and able to live clean and healthy. Through this EMA education, it is hoped that disease vector control can be sustained. So that in the end awareness and concern for the importance of a clean and healthy life and a healthy environment can grow well in students.

Eradication of the dengue mosquito vector at an early stage requires a precise and complete method for optimal results. Modifications, manipulations and changes to student habits need to be done so that efforts to combat dengue can be successful. This method is a process in the implementation of EMA (Environmental Management Action) in controlling the vector of DHF according to WHO guidelines, where this EMA method has been carried out in America in the prevention and control of DHF vectors [7]. For this reason, research on "Environmental Management Action (e-Modification, Manipulation, and Changes to Human Habitation) needs to be carried out in involving students to Combat DHF. 


\section{Method}

The study was conducted with a one group pretest posttest design. Samples were taken by purposive sampling with a total of 24 students. The research data was processed using a quantitative descriptive approach. The solution offered for partner problems is EMAEnvironmental Management Action (Modification, Manipulation, and Changes to Human Habitation) Education in Combating DHF in coastal areas. This method is offered because the target is junior high school students who are expected to become agents of change. The implementation of EMA education in fighting dengue by students begins with coordination with the principal and teacher guardians for the implementation of activities, then disseminates to teachers and students, and organizes students for EMA.

Target students are given training in implementing the EMA, namely:

a. Action Modification of the environment at home and around the house

b. Home Environment Manipulation Action and around the house

c. Behavior Change Action for Family Members

The implementation of EMA is carried out at the household level whose implementation is assisted by students in preventing DHF. The success of preventing DHF through the application of EMA by students must be supported by stakeholders, the community, community leaders and religious leaders in order to be successful and sustainable.

Through this activity, it is hoped that the following benefits can be taken:

a. Increase the monitoring of dengue vectors by students, so that household awareness to maintain personal and environmental hygiene increases.

b. Instilling the attitude of clean and healthy life behavior (PHBS) in students.

c. Improve the sustainability of the program for the prevention and control of DHF by students.

d. Environmental management seeks to change the environment to prevent or minimize vector spread and human contact with pathogens by destroying, altering, removing or recycling non-essential containers that provide habitat for Aedes aegypti larvae. This action should be a mainstay of dengue vector control.

The type of environmental management is defined:

- Environmental modification and manipulation - changes to vector habitats that involve managing containers and environments critical to preventing the emergence of breeding places for mosquitoes, such as frequent emptying and cleaning by scrubbing of water storage vessels, flower vases and desert air conditioning; cleaning gutters; protects stored tires from rain; recycling or proper disposal of discarded containers and tires; Management or removal of surrounding plants such as ornamental or wild bromeliads that collect water in leaf axils.

- Changes in human habitation or behavior - measures to reduce human-vector contact, such as installing mosquito screens on windows, doors and other entry points, and using mosquito nets while sleeping during the day. The choice of approach must be effective, practical and appropriate to local circumstances. Important actual or potential container types that cannot be removed from the area should be handled in situ. 
Stages of Implementing Environmental Management Action Education in Student Engagement to Combat DHF in Coastal Areas:

1. Licensing and coordination with the Principal

2. Outreach with Teachers and Students at school

3. Preparation of guidelines for implementing EMA education.

4. Implementation of EMA Education by the student service team, namely 1) Modification Action in the home environment and its surroundings, 2) Action to Manipulate the Environment and its surroundings and 3) Behavior Change Action for students and Family Members

5. Direct practice of environmental prevention and control with the EMA Method by students.

6. The process of measuring the results of service and data processing

7. Evaluation and dissemination of community service activities

The data collection instrument was a questionnaire to measure EMA knowledge, attitudes and practices. The target audience for this Community Service is Students at the Sultan Agung 4 Islamic Junior High School in Semarang.

\section{Result and Discussion}

SMP Islam Sultan Agung 4 Semarang is one of the junior high schools in the city of Semarang. This school consists of 364 students who are divided into 14 classes, for this new academic year the female students are separated from the female students. SMP Islam Sultan Agung 4 whose address is Jl. Raya Kaligawe KM. 4, Genuk Semarang City, Central Java Province 50112. The main activity at the school is teaching and learning, which is complemented by religious and extracurricular activities every evening. Most of the students and students who attend Islamic Junior High School Sultan Agung 4 Semarang come from subdistricts which are endemic areas for DHF, namely Genuk, Terboyo, Tambak Lorok and Tri Mulyo sub-districts.

Activities began in April 2019. The research began with coordination and licensing with school leaders. After being allowed to research at school by the management, the research team coordinated with the school administrator. After determining a schedule that was adjusted to the student's time, the researchers conducted interviews with school administrators regarding the clean and healthy lifestyle of the students and also about the behavior of maintaining environmental sanitation in preventing the dengue vector disease in their homes and around their homes.

The results of the interview with the school stated that the health problems that occurred in students were dermatitis (rashes on the skin), scabies, in addition to dengue fever. The state of personal hygiene for each student is still lacking, for example, rarely changing clothes, throwing garbage in the gutter, throwing trash in the classroom desk drawer, throwing trash in the school yard. While the condition of the cleanliness of the environment around the school is around the school surrounded by sewers, tidal water often stagnates every 14.00-15.00 WIB. It is also possible that their behavior at home is reflected in their behavior at school. For this reason, pengabdi began to conduct education services for Environmental Management Action to help students in fighting dengue in their homes and around their homes.

Respondents consisted of 24 students of SMP Islam Sultan Agung 4 Semarang who were randomly selected from each class so that they became agents of change in their respective classes after service activities were completed. EMA education is provided using the guidelines in Table 1. 
Table 1. EMA Education for Students in Preventing DHF in students in Coastal Areas

\begin{tabular}{|c|c|c|}
\hline No & Criteria & $\begin{array}{c}\text { Environmental Management Action (EMA) Education in } \\
\text { Preventing DHF }\end{array}$ \\
\hline 1 & $\begin{array}{l}\text { Environmental } \\
\text { modification } \\
\text { and } \\
\text { manipulation }\end{array}$ & $\begin{array}{l}\text { Provide a closed trash can } \\
\text { Keeping the trash can clean } \\
\text { Ensure that waste can flow smoothly to the disposal site / does not stagnate } \\
\text { Empty the container that can serve as a water reservoir } \\
\text { Using a non-permanent bathtub (bucket) } \\
\text { Use of closed latrines } \\
\text { Manage trash } \\
\text { Keeping the bathtub clean } \\
\text { Change the water in the flower vase / bird drinking water regularly at least } \\
\text { once a week } \\
\text { Change the bird's drinking water regularly at least once a week } \\
\text { Raising fish to eat mosquito larvae in ponds that are difficult to clean } \\
\text { Managing used materials / bottles in the environment around the house }\end{array}$ \\
\hline 2 & $\begin{array}{l}\text { Changes in } \\
\text { behavior }\end{array}$ & $\begin{array}{l}\text { People of all walks of life and age groups must participate in eradicating } \\
\text { mosquito nests } \\
\text { Drain the bath once a week } \\
\text { Close the water reservoir } \\
\text { Maintain Cleanliness of water reservoirs } \\
\text { Don't hang clothes } \\
\text { Wearing a mosquito net while sleeping in the early morning } \\
\text { Apply mosquito repellent if necessary } \\
\text { Check for the presence of mosquito larvae once a week in their own homes } \\
\text { and residents' homes } \\
\text { Tell the public to do the } 3 \mathrm{M} \text { Plus DBD PSN behavior } \\
\text { The implementation of } 3 \mathrm{M} \text { Plus starts with yourself and your family } \\
\text { All people must carry out the } 3 \mathrm{M} \text { Plus PSN regularly and simultaneously } \\
\text { Immediately dispose of larvae living in puddles } \\
\text { Check your health immediately if you find symptoms such as dengue fever }\end{array}$ \\
\hline
\end{tabular}

Table 2. Results of Environmental Management Action (EMA) Education in Preventing DHF

\begin{tabular}{|c|c|c|c|c|}
\hline \multirow[t]{2}{*}{ No. } & \multirow[t]{2}{*}{ Variable } & \multicolumn{3}{|c|}{ Application of EMA } \\
\hline & & $\begin{array}{c}\text { Average } \\
\text { Before }(\%)\end{array}$ & $\begin{array}{l}\text { Average } \\
\text { after }(\%)\end{array}$ & delta \\
\hline 1 & Students' knowledge about DHF & 63,3 & $84,2 *$ & 20,9 \\
\hline 2 & Students' Attitudes in Preventing DHF & 45,8 & $76,7 *$ & 30,9 \\
\hline 3 & Environmental Modification and Manipulation & 86,7 & $92,5^{*}$ & 5,8 \\
\hline 4 & Behavior changes in preventing DHF & 94,6 & $97,5 *$ & 2,9 \\
\hline & $\begin{array}{l}\text { The Average Score of Improved DHF } \\
\text { Prevention }\end{array}$ & 72,6 & 87,7 & 15,1 \\
\hline
\end{tabular}

Source: Primary Data, 2020

The results of EMA education in schools show that there is an increase in both Student Knowledge about DHF, Student Attitudes in Preventing DHF, Environmental Modification and Manipulation, and also in Behavior Change in preventing DHF. We can see the highest increase in the highest delta, namely the variable Attitudes of Students in Preventing DHF. 
Efforts to prevent the spread of DHF can be done by utilizing the potential of existing resources. There are several potential resources that can be managed in preventing the spread of DHF; (1) The potential to utilize natural resources as an effort to cultivate mosquito repellent plants. (2) Potential utilization of the PHBS program as a manifestation of a healthy paradigm in shaping clean and healthy living habits, and (3) Utilization of symmetrical environmental management in the Aedes aegypti mosquito-borne attack environment and human activity environment as a potential for environment-based prevention of disease spread [8].

Students as members of the community participate actively in activities to prevent Dengue Hemorrhagic Fever from an early age through environmental management actions. Communication, information and education provided to students by involving discussions and group discussion forums will foster motivation and awareness in creating a solid team for the management of DHF prevention. Interventions that are formed based on mutual agreement and according to students' abilities will form the foundation for the sustainability of the program after the implementation of the research..

Institutions such as schools are places that have the potential to become a habitat for disease vector development. School canteens that do not get enough attention can be the cause of the arrival of vectors, including waste which must always be managed properly. Vector control can be done with a single method or integrated vector control. Vector control can be done biologically, chemically, physically / mechanically, genetic engineering for vectors or through environmental management [9-12]. Vector control in schools should be followed by the involvement of all elements of its inhabitants who are the subject of vector control implementation, namely teachers, students and food vendors in the canteen. vector control that involves the role of all parties including stake holders in schools will make the program sustainable [5].

Willingness to take preventive measures and vector control supported by intensive coordination will result in behavior that can last a long time, so that it can become a habit. [13]. Research conducted in Malaysia on the control activity of the Aedes aegypty mosquito states that most of the cost of preventing dengue fever is spent on fogging[14] As in Indonesia, most people still think that fogging is the most appropriate choice for eradicating mosquito nests. In fact, fogging is a chemical vector control whose use should be minimized because it is less environmentally friendly [15]. Fogging can cause environmental pollution and mosquitoes become resistant if the dosage used is not correct. In addition, fogging activities should be an alternative if the environment is already an emergency due to a dengue outbreak [16]. If there has been no dengue outbreak, the community should carry out activities to eradicate mosquito nests by burying, closing and draining the tub every 1 time a week regularly and simultaneously to all communities [10].

The prevention and control of DHF in the community is the responsibility of all parties in the community [11]. Such as community leaders, religious leaders, local government, and community members themselves who are at the forefront of successful environmental management in preventing infectious diseases [17]. Strengthening at the family level is very important because the basis for the sustainability of environmental management in the household is very much influenced by family members including parents and children. Prevention and control of DHF in the household or family, in essence, is to involve parents (father and mother) as the head of the family, students / children to participate in driving activities to eradicate the mosquito nest of dengue disease in the home and in the surrounding environment. So it is hoped that environmental management action can run sustainably [9], [18], [19]. 


\section{Conclusion}

The results of EMA education in schools show that there is an increase in both Student Knowledge about DHF, Student Attitudes in Preventing DHF, Environmental Modification and Manipulation, and also in Behavior Change in preventing DHF. We can see the highest increase in the highest delta, namely the variable Attitudes of Students in Preventing DHF. EMA education can be an alternative in increasing awareness and attitudes of students to maintain their behavior in preventing DHF in their environment.

Acknowledgments. Thanks to the Faculty of Sports Science and LP2M Universitas Negeri Semarang for providing research funding.

\section{References}

[1] K. Alagarasu, T. Honap, Mulay, Bachal, Shah, and Cecilia, "Association of vitamin D receptor gene polymorphisms with clinical outcomes of dengue virus infection," Human Immunology vol. Vol 73 (2012) 1194-1199, 2012.

[2] N. Siyam, Siswanto Agus Wilopo, and Muhammad Hakimi, "Asupan Vitamin D Rendah dan Keparahan Demam Berdarah Dengue pada Anak Usia 1-14 Tahun," Kesmas UI: Jurnal Kesehatan Masyarakat Nasional, vol. Vol. 9, No. 1, Agustus 2014, 2014.

[3] A. J. Cornel, J. Holeman, C. C. Nieman, Y. Lee, C. Smith, M. Amorino, K. K. Brisco, R. Barrera, G. C. Lanzaro, and F. S. Mulligan Iii, "Surveillance, insecticide resistance and control of an invasive Aedes aegypti (Diptera: Culicidae) population in California," F1000Res, vol. 5, p. 194, 2016.

[4] P. R. Packierisamy, C. W. Ng, M. Dahlui, J. Inbaraj, V. K. Balan, Y. A. Halasa, and D. S. Shepard, "Cost of Dengue Vector Control Activities in Malaysia," Am J Trop Med Hyg, vol. 93, pp. 1020-7, Nov 2015

[5] N. Siyam, "Integrated and Comprehensive Action to Reduce and Control Dengue Hemorrhagic Fever: A Survey in Pekalongan City, Central Java," Tropical Medicine Journal, vol. 03 No. 1, pp. 85-93, 2013.

[6] ADB and WHO, Managing Regional Public Goods for Health, Community-Based Dengue Vector Control. Cambojia: WHO, 2013.

[7] WHO and TDR, Dengue, Guidlines for Diagnosis, Treatment, Prevention and Control. Geneva, Switzerland: WHO Press, 2009.

[8] L. R. Bowman, S. Donegan, and P. J. McCall, "Is Dengue Vector Control Deficient in Effectiveness or Evidence?: Systematic Review and Meta-analysis," PLoS Negl Trop Dis, vol. 10, p. e0004551, Mar 2016.

[9] C. M. Mutero, D. Schlodder, N. Kabatereine, and R. Kramer, "Integrated vector management for malaria control in Uganda: knowledge, perceptions and policy development," Malaria Journal, vol. 11, pp. 1-10, 2012.

[10] S. E. Naranjo and P. C. Ellsworth, "Fifty years of the integrated control concept: moving the model and implementation forward in Arizona," Pest management science, vol. 65, pp. 1267-1286, Dec 2009.

[11] H. van den Berg, A. von Hildebrand, V. Ragunathan, and P. K. Das, "Reducing vector-borne disease by empowering farmers in integrated vector management," Bull World Health Organ, vol. 85, pp. 561-566, Jul 2007.

[12] D. Zhang, X. Zheng, Z. Xi, K. Bourtzis, and J. R. Gilles, "Combining the sterile insect technique with the incompatible insect technique: I-impact of wolbachia infection on the fitness of triple- and doubleinfected strains of Aedes albopictus," PLoS One, vol. 10, pp. 121-126, 2015.

[13] N. Siyam, "Strengthening of Self Care Management To Improve Clean And Healthy Lifestyle Habits of Female Santri Efforts As Candidate As Preparation of Mother," in 2nd International Seminar on Public Health and Education, Semarang City, 2015. 
[14] P. R. Packierisamy, C. W. Ng, M. Dahlui, J. Inbaraj, V. K. Balan, Y. A. Halasa, and D. S. Shepard, "Cost of Dengue Vector Control Activities in Malaysia," American Journal Tropical Medicine and Hygiene, vol. 93, pp. 1020-1027, Nov 2015.

[15] E. Chanda, B. Ameneshewa, S. Mihreteab, A. Berhane, A. Zehaie, Y. Ghebrat, and A. Usman, "Consolidating strategic planning and operational frameworks for integrated vector management in Eritrea," Malaria Journal, vol. 14, p. 488, 2015.

[16] F. Zhu, L. Lavine, S. O'Neal, M. Lavine, C. Foss, and D. Walsh, "Insecticide Resistance and Management Strategies in Urban Ecosystems," Insects, vol. 7, pp. 1-26, 2016.

[17] K. M. Lizzi, W. A. Qualls, S. C. Brown, and J. C. Beier, "Expanding Integrated Vector Management to promote healthy environments," Trends Parasitol, vol. 30, pp. 394-400, Aug 2014.

[18] E. Chanda, J. M. Govere, M. B. Macdonald, R. L. Lako, U. Haque, S. P. Baba, and A. Mnzava, "Integrated vector management: a critical strategy for combating vector-borne diseases in South Sudan," Malaria Journal, vol. 12, pp. 1-9, 2013.

[19] E. Nalwanga and J. C. Ssempebwa, "Knowledge and practices of in-home pesticide use: a community survey in Uganda," Journal of Environmental and Public Health, vol. 2011, pp. 1-7, 2011. 